\title{
A rapid survey of large branchiopods in Romania
}

\author{
L. Demeter ${ }^{1 *}$, T. Hartel ${ }^{2}$ \\ ${ }^{1}$ Sapientia Hungarian University of Transylvania, Department of Technical and Nature Sciences, 530104 Miercurea-Ciuc, pța. Libertății nr. 1, Romania. \\ ${ }^{1}$ Mircea Eliade College, 545400 Sighişoara, str. 1 Decembrie nr. 31, Romania
}

Romania has a unique diversity of large branchiopods in Europe, but the present distribution of species is poorly documented. This note is a summary of a survey aimed at a rapid assessment of large branchiopod occurrence and frequency at a landscape level. The survey was conducted in ten landscapes, and it lasted from 2004 to 2006, recording fifteen species. Most species $(80 \%)$ were only found in one or two landscapes, showing large differences in species composition between landscapes and possibly an underestimation of some species. Four landscapes had a frequency of large branchiopod habitats greater than $30 \%$ and together contained all the species found during the survey. Based on the relatively large detection probabilities found during this survey we suggest that a country-level distribution database could be done in a short time period (in a few years) even with few participants. Target areas for further distribution surveys should be the localities described in the published literature, flat lands and middle to large river valleys.

Keywords: large branchiopods, distribution, Romanian Plain, Ciuc basin, Banat

\section{Introduction}

Romania has the second largest number of large branchiopod species in Europe after Russia. Up till now, 28 species have been recorded (Botnariuc \& Orghidan 1953, Stoicescu 1991, Demeter 2005). For a comparison, 22 species are known in Italy (Cottarelli et al. 1995, Mura 1999), 19 in Hungary (Forró 2000) and in Serbia and Montenegro (Cvetković-Milićič \& Petrov 2001), 18 in France (Defaye et al. 1998), 17 in Spain (Alonso 1985) and 16 in Austria (Eder and Hödl 2002). The number of species in European Russia approaches 40 (Vekhoff 1993). The high species richness of the Romanian Plain was noted already by Botnariuc (1948). Four endemic species have been accepted for this area: $\mathrm{Chi}$ rocephalus orghidani Brtek, 1966, Branchipus intermedius Orghidan, 1947, Tanymastix motasi Orghidan, 1945, and Lynceus andronachensis Botnariuc, 1947 (Botnariuc \& Orghidan 1953, Belk \& Brtek 1995). One more endemic species, Chirocephalus robustus Müller, 1966, was described from Transylvania (Müller 1966). Two species present on the Western Romanian Plain (Chirocephalus carnuntanus Brauer, 1877 and Chirocephalus brevipalpis Orghidan, 1952) are Pannonic endemisms (Löffler 1993). Drepanosurus hankoi Dudich, 1927, previously considered a Pannonic endemism (Löffler 1993), was found recently in Belorussia (Nagorskaja et al. 1998) and in Romania (Demeter 2004).

\footnotetext{
* Corresponding author: demeterlaszlo@sapientia.siculorum.ro
}

No large branchiopod species are listed in the European nature conservation directives, however several countries (e.g. Austria, Great Britain and Germany) have Red Lists of large branchiopods and protected species (Cvetković-Milićič \& Petrov 2001). None of the species are protected in Romania at the national level, but recently five species were included in the list of protected species of one county (County Council Decision nr. 162/2005 of Harghita county). Due to the large number of endemisms in Romania and due to the vulnerability of their habitats (temporary ponds), it is necessary to develop a national level conservation plan for large branchiopods. For this, comparative data are needed on their local and regional distribution. The last comprehensive study on the distribution of large branchiopods in Romania dates from the 1950's (Botnariuc \& Orghidan 1953). Very little research has been done since then (e. g. Stoicescu 1967, 1991, Demeter, 2004, 2005). The old literature is deficient when it comes to relocate the habitats (usually only the names of the localities are provided) and the assessment of changes in species frequency, habitat quality and availability is practically impossible because of lack of data. The goal of this study was to: (1) assess the distribution of large branchiopods in several Romanian landscapes in a short time period, (2) collect data on the frequency of large branchiopods as a group, and (3) collect data on the relative frequency of species at a landscape level. 


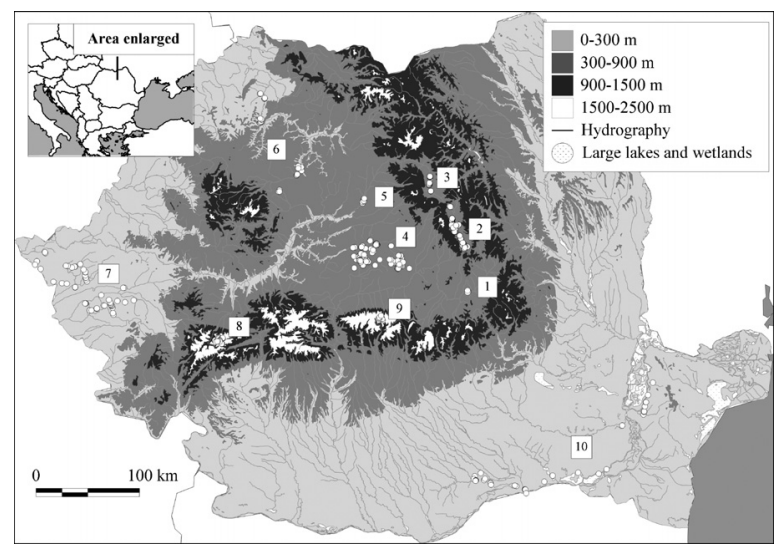

Fig. 1. Map of the studied landscapes with the location of the surveyed habitats (small white dots). 1-Reci, 2-Ciuc basin, 3-Gheorgheni basin, 4-Târnava Mare valley, 5-Mureş valley, 6-Someş valley, 7-Banat plain, 8-Retezat mountains, 9-Făgăraş mountains, 10-Lower Danube

\section{Methods}

We visited ten Romanian landscapes from 2004 to 2006, a landscape being defined as a geographical unit (basin, river valley, mountain or plain) where at least ten habitats were surveyed in the current study (Fig. 1). The visited landscapes were selected to comprise the localities where the largest number of species had been recorded by previous studies (Botnariuc \& Orghidan 1953, Stoicescu 1967, Bănărescu 1996), but some new landscapes were investigated too. Data from occasional collections are not included in this paper. A total of approximately 670 potential habitats were checked in total for the presence of large branchiopods. We considered as potential habitats small wetland bodies in their aquatic phase at the time of survey. We searched for potential habitats during transects within a landscape by car, bicycle and on foot. Large branchiopods were searched for through visual observation and netting, preserved in $70 \%$ ethanol or $4 \%$ formol, and identified using Botnariuc \& Orghidan (1953) and Brtek \& Mura (2000). Most of the field work was carried out in spring (between March and May), but some sites were surveyed in summer and autumn (July, August and September). We recorded the geographic location of habitats with a Garmin GPS 72, and we estimated the agricultural land use composition in the surroundings of the habitat. For each landscape we calculated: (1) the frequency of large branchiopods as the number of habitats with at least one species divided by the total number of habitats surveyed and (2) the relative frequency of individual species as the number of habitats where the species was found divided by the number of all large branchiopod habitats. The distribution data for the Ciuc basin and Retezat mountains published previously (Demeter 2004, 2005, Demeter \& Mori 2004) were completed with new data for the current study.

\section{Results and discussion}

Fifteen species were found during the survey, which is $53.6 \%$ of the known number of species in Romania (Table 1). Out of these, eleven were found in one or two landscapes only (Chirocephalus brevipalpis, $C$. carnuntanus, Drepanosurus hankoi, Tanymastix stagnalis Linné, 1758, Lepidurus couesii Packard, 1875, Streptocephalus torvicornis Waga, 1842, Lepidurus apus Linné, 1758, Leptestheria dahalacensis Rüppell, 1837, Cyzicus tetracerus Krynicki, 1830, Eoleptestheria ticinensis Balsamo-Crivelli, 1859, Lynceus brachyurus Müller, 1776), and four species were found in three to five landscapes (Branchipus schaefferi $\mathrm{Fi}-$ scher, 1834, Chirocephalus diaphanus Prévost, 1803, C. shadini Smirnov, 1928, Triops cancriformis Bosc, 1801). This suggests a high beta diversity of large branchiopods in Romania. Three species found during the first year of the survey were new to the Romanian fauna (Demeter 2004). Several recorded species are rare or data-deficient: we found one new habitat of C. carnuntanus, a species that has only three literature records dating from 1985-1987 (Stoicescu 1991), and a new habitat of Lepidurus couesii, a species that had been recorded only once in Romania (Botnariuc \& Orghidan 1953). This habitat is approximately $60 \mathrm{~km} \mathrm{SW}$ from the originally described location, and thus it is the westernmost known occurrence of $L$. couesii in $\mathrm{Eu}-$ rope. On the other hand, none of the species endemic to the Romanian Plain and Transylvania were found during this survey. The frequency of large branchiopods in potential habitats varied from $1.5 \%$ in Târnava Mare valley to $43.5 \%$ in Somes valley. Half of the surveyed landscapes had a frequency of large branchiopods greater than $25 \%$ (Table 2). The number of species was greatest in the Ciuc basin (8) and Lower Danube (6), and least in the high mountains (1).

Information regarding the frequency of the group and the relative frequency of species could be helpful when prioritizing conservation activities on the national and local (landscape) level. We consider that species with a relative frequency of less than $20 \%$ at the landscape level are very rare, and need protection. Those species were $C$. carnuntanus (Banat Plain), D. hankoi, T. stagnalis (Ciuc basin), L. couesii (Lower Danube) (Table 1). T. stagnalis is a relatively widespread species in Western Europe (Brtek \& Thiéry 1995), but it was found in Romania only very recently 
Table 1. Species list, the regions in which they were found (relative frequency of the species in brackets), the altitudinal range of each species and the month when adults were found. B-Banat Plain, C-Ciuc basin, D-Lower Danube, F-Făgăraş mountains, G-Gheorgheni basin, M-Mureş valley, R-Reci, RMRetezat mountains, S-Someş valley, T-Târnava Mare valley.

\begin{tabular}{|c|c|c|c|c|}
\hline $\begin{array}{l}\text { Species grouped in families } \\
\text { (according to Brtek and } \\
\text { Thiéry (1995)) }\end{array}$ & $\begin{array}{l}\text { Surveyed landscape (relative } \\
\text { frequency of species) }\end{array}$ & 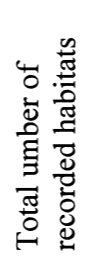 & 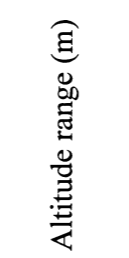 & 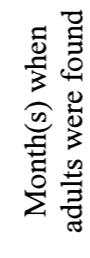 \\
\hline \multicolumn{5}{|l|}{ Branchipodidae } \\
\hline Branchipus schaefferi & D (56\%), S (70\%) & 16 & $1-38$ & $5,8,9$ \\
\hline $\begin{array}{l}\text { Tanymastix stagnalis } \\
\text { Streptocephalidae }\end{array}$ & $\mathrm{C}(2 \%)$ & 1 & 670 & 4,8 \\
\hline $\begin{array}{l}\text { Streptocephalus torvicornis } \\
\text { Chirocephalidae }\end{array}$ & C (2\%), D (25\%) & 5 & $47-73$ & 5,8 \\
\hline Chirocephalus brevipalpis & B (30\%) & 6 & $90-118$ & 4 \\
\hline C. carnuntanus & $\mathrm{B}(5 \%)$ & 1 & 113 & 4 \\
\hline C. diaphanus & $\begin{array}{l}\text { T (50\%), B (65\%), F, M, RM } \\
\text { (each 100\%) }\end{array}$ & 31 & $83-2260$ & $4,7,8$ \\
\hline C. shadini & C, G (each $80 \%), \mathrm{R}(100 \%)$ & 53 & $520-730$ & 4,5 \\
\hline $\begin{array}{l}\text { Drepanosurus hankoi } \\
\text { Triopsidae }\end{array}$ & C $(10 \%), \mathrm{R}(33 \%)$ & 7 & $520-720$ & 3,4 \\
\hline Lepidurus apus & C (21\%), R (33\%) & 14 & $520-720$ & 4 \\
\hline L. couesii & $\begin{array}{l}\text { D (6\%) } \\
\text { C (3\%), G (20\%), D (25\%), B }\end{array}$ & 1 & 12 & 4 \\
\hline Triops cancriformis & $\begin{array}{l}(35 \%), \mathrm{S}(30 \%), \mathrm{T}(50 \%), \mathrm{M} \\
(100 \%)\end{array}$ & 18 & $5-730$ & $5-9$ \\
\hline Cyzicidae & & & & \\
\hline $\begin{array}{l}\text { Cyzicus tetracerus } \\
\text { Leptesheriidae }\end{array}$ & $\mathrm{D}(13 \%)$ & 2 & $5-13$ & 5 \\
\hline Eoleptestheria ticinensis & C (20\%), R (33\%) & 12 & $520-700$ & $4,5,6$ \\
\hline $\begin{array}{l}\text { Leptestheria dahalacensis } \\
\text { Lynceidae }\end{array}$ & $\mathrm{D}(31 \%)$ & 5 & $1-47$ & 5 \\
\hline Lynceus brachyurus & C (31\%), R (33\%) & 19 & $520-700$ & $4,5,6$ \\
\hline
\end{tabular}

(Demeter 2004, 2005). Some species were found to be rare on the landscape level as S. torvicornis and T. cancriformis in the Ciuc basin, but widespread on the national level based on literature data (S. torvicornis) and this study (T. cancriformis). On the other hand, $C$. shadini is a rare species at the national level, but frequent in three studied mountain basin landscapes where it is known to occur. Other frequent species on the landscape level (above $70 \%$ ) were $C$. diaphanus and B. schaefferi (Table 1).

Most large branchiopod habitats were found in open agricultural landscape (Table 2). Only one habitat of C. diaphanus was found in forest in the Târnava Mare valley. The most frequent large branchiopod habitats were natural ponds in the Ciuc basin, Gheorgheni basin and Reci (the most frequent species is $C$. shadini), and in the Retezat mountains $(C$. diaphanus), wheel rut pools on dirt roads in the Somes valley (B. schaefferi), and ponds on arable land in the Banat (every recorded species was represented in this pond type). Along the Lower Danube the recorded large branchiopod habitats were ponds on arable fields, wet pastures and wheel rut pools.

In four of the studied landscapes, all records collected in the present survey are new. In the Ciuc basin the number of recorded species increased from six (Demeter 2005) to eight. In three landscapes we recorded fewer species than that described in the literature. The largest difference was for the Lower Danube (part of the Romanian Plain) where only $37.5 \%$ of the previously recorded species (six out of 16) were found during the current survey (Table 2). However, we sampled only a small part of this large area. 
Table 2. List of landscapes surveyed, number of species found during this survey and by previous studies (B=Bănărescu 1996, BO=Botnariuc and Orghidan 1953, D=Demeter 2005), number and frequency of large branchiopod habitats and number of habitats surveyed.

\begin{tabular}{|c|c|c|c|c|c|}
\hline Landscape & $\begin{array}{l}\text { Dominant land } \\
\text { use type }\end{array}$ & 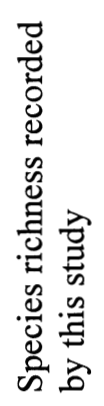 & 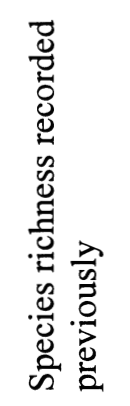 & 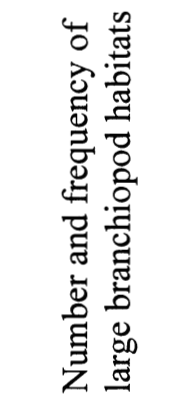 & 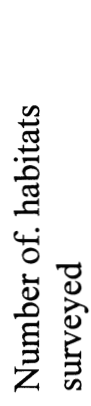 \\
\hline Ciuc basin & $\begin{array}{l}\text { hay meadow, } \\
\text { arable land }\end{array}$ & 8 & $6(\mathrm{D})$ & $61(30.5 \%)$ & 200 \\
\hline Târnava Mare valley & $\begin{array}{l}\text { deciduous } \\
\text { forest }\end{array}$ & 2 & 0 & $2(1.5 \%)$ & 200 \\
\hline Banat plain & arable land & 4 & $6(\mathrm{~B})$ & $20(35.1 \%)$ & 57 \\
\hline Retezat mountains & alpine pasture & 1 & $1(\mathrm{BO})$ & $16(28 \%)$ & 57 \\
\hline Gheorgheni basin & hay meadow & 2 & 0 & $10(25 \%)$ & 50 \\
\hline Lower Danube & $\begin{array}{l}\text { pasture, arable } \\
\text { land }\end{array}$ & 6 & $\begin{array}{c}16 \\
\text { (BO) }\end{array}$ & $16(36.4 \%)$ & 44 \\
\hline Someş valley & arable land & 2 & $4(\mathrm{BO})$ & $9(43.5 \%)$ & 23 \\
\hline Făgăraş mountains & alpine pasture & 1 & $1(\mathrm{BO})$ & $1(6.3 \%)$ & 16 \\
\hline Reci & pasture & 5 & 0 & $3(21.4 \%)$ & 14 \\
\hline Mureş valley & $\begin{array}{l}\text { pasture, arable } \\
\text { land }\end{array}$ & 2 & 0 & $1(8.3 \%)$ & 12 \\
\hline
\end{tabular}

Only in two landscapes (Ciuc basin and Târnava Mare valley) is the habitat sample size large enough to form a reliable picture of the current frequency of large branchiopods and the relative frequency of species. Of these, the Ciuc basin (at $650 \mathrm{~m}$ a.s.l) is unexpectedly species-rich, and should be a target for further research, monitoring and conservation. The low species number and low frequency of large branchiopods in the Târnava Mare valley could be explained by the topography and vegetation of the area (forested hills) and/or by high predator pressure (presence of fish and newts). For the other surveyed landscapes the data presented here are estimations that could be useful for preliminary conservation actions and a baseline for further studies.

Although far from complete, our data show that a high diversity of large branchiopods is still present in Romania. This is probably related to the landscape variability of this country (five biogeographic regions are represented), the continental precipitation patterns and the large surface of lowlands. In agreement with the literature (Botnariuc and Orghidan 1953, Brtek and Thiéry 1995), our data show that the areas with the largest number of species tend to be flatlands and open areas. In more than half of the surveyed landscapes we found frequency values of large branchiopods as a group larger than $25 \%$, suggesting a high detection probability of large branchiopod habitats. Half of the known species have been found with a relatively small effort spent on eight landscapes (around 270 surveyed habitats in total) and a larger effort spent on two landscapes (around 200 surveyed habitats each). This indicates that a country-level distribution database could be established in a relatively short time (up to 5 years) even with few participants. The target sites for such a project should be the flat lands, middle to large river valleys and the localities described in the old literature. 


\section{Acknowledgements}

We thank Demeter István, Kelemen Alpár, Nicholas and Mirona Meade, Török Etelka who helped in the field work. The comments of Graziella Mura, Liubov Nagorskaya and Pascale Nicolet were much appreciated. The research benefited from a DAPTF seed grant in 2004 and from a stipend of the Sapientia Institute of Research Programs in 2005.

\section{References}

Alonso M. 1985. - A survey of the Spanish Euphyllopoda. Misc. Zool., 9, 179-208.

Bănărescu P.M. 1996. - Reduction of the biodiversity of the aquatic fauna of the Banat. Analele Banatului, Muzeul Banatului Timișoara, 5, 99-105.

Belk D. \& Brtek J. 1995. - Checklist of the Anostraca. Hydrobiologia , 298, 315-353.

Botnariuc N. 1948. - Considerations sur l'importance biogeographique de la faune des eaux periodiques de la Plaine Roumaine. Bulletin de la Section Scientifique L'Academie de la Republique Roumaine, 30(9), 570-577.

Botnariuc N. \& Orghidan T. 1953. - Crustacea, Phyllopoda. Fauna R.P.R., vol. IV, fasc. 2. Editura Academiei R.P.R., București. [in Romanian].

Brtek J. \& Mura G. 2000. - Revised key to families and genera of the Anostraca with notes on their geographical distribution. Crustaceana, 73, 1037-1088.

Brtek J. \& Thiéry A. 1995. - The geographic distribution of the European branchiopods (Anostraca, Notostraca, Spinicaudata, Laevicaudata). Hydrobiologia, 298, 263-280.

Cottarelli V., Fiorenza G.M. \& Mura G. 1995. - Crustacea Branchiopoda. In Checklist delle specie della fauna Italiana, 25. Minelli A., Ruffo, S. \& La Posta S. (eds.). Calderini, Bologna.

Cvetković-Milićič D. \& Petrov B. 2001. - A review of the diversity of large branchiopods (Anostraca, Notostraca and Conchostraca) in countries of former Yugoslavia and some other parts of Europe - status, endangerment and conservation. Ekologija, 36, 101-123.

Defaye D., Rabet N. \& Thiéry A. 1998. - Atlas et bibliographie des crustacés branchiopodes (Anostraca, Notostraca, Spinicaudata) de France métropolitaine. MNHN, Paris, $61 \mathrm{p}$.
Demeter L. 2004. - The spatial distribution of three species of Anostraca in the Ciuc-basin. Studii și Cercetări Ştiinţifice, Seria Biologie, Universitatea Bacău, 9, 42-47.

Demeter L. 2005. - Spatial distribution patterns and conservation status of large branchiopods in the Ciuc Basin. Acta Biol. Debr. Oecol. Hung., 13, 73-83.

Demeter L. \& Mori C. 2004. - Spatial distribution and habitat characteristics of Chirocephalus diaphanus (Branchiopoda: Anostraca) in the Retezat mountains. Biota, 5, 11-23.

Eder E. \& Hödl W. 2002. - Large freshwater branchiopods in Austria: diversity, threats, and conservational status. Pages 281-289 in Modern approaches to the study of Crustacea. Escobar-Briones E. \& Alvarez F. (eds). Kluwer Academic/Plenum Publishers, New York.

Forró L. 2000. - Checklist, distribution maps and bibliography of large branchiopods in Hungary (Anostraca, Notostraca, Spinicaudata, Laevicaudata). Miscellanea Zoologica Hungarica, 13, 47-58.

Löffler H. 1993. - Anostraca, Notostraca, Laevicaudata and Spinicaudata of the Pannonian Region and in its Austrian area. Hydrobiologia, 264, 169-174.

Mura G. 1999. - Current status of the Anostraca of Italy. Hydrobiologia , 405, 57-65.

Müller G. I. 1966. - Chirocephalus spinicaudatus robustus n. spp. (Phyllopoda, Anostraca), description and notes on its biology. Studii și Cercetări de Biologie, Seria Zoologie, 18 (3), 217-220. [in Romanian].

Nagorskaja L., Brtek J. \& Mura G. 1998. - The anostraca of the Republic of Belarus. Hydrobiologia, 367, 21-30.

Stoicescu A. 1967. - Contributions to the knowledge on the distribution of phyllopods in the surroundings of Oltenița town. Natura, Seria Biologie, 5, 75-78. [in Romanian].

Stoicescu A. 1991. - Pristicephalus carnuntatus (Phyllopoda, Anostraca), espéce nouvelle pour la faune de Roumanie. Revue Roumaine Biologie, Biologie Animale, 36(1-2), 27-32.

Vekhoff N.V. 1993. - The fauna and zoogeography of fairy and tadpole shrimps of Russia and adjacent lands (Crustacea: Anostraca, Notostraca). Arthropoda Selecta, 2 (3), 11-42. 